\title{
SOCIAL MEDIA AND BRIDGING OF COVID-19 INFORMATION GAP AMONG STUDENTS OF FEDERAL POLYTECHNIC, OKO
}

\author{
Onyeka Uwakwe, $\mathrm{PhD}$, fimim, arpa, anipr \\ Department of Mass Communication, \\ Federal Polytechnic, Oko \\ doconyekauwakwe@gmail.com \\ 08034097091
}

\begin{abstract}
This is a survey study. The researcher uses a sample of 112 students to $x$-ray the impact of new media in dissemination information on COVID-19 pandemic. The study submits that WhatsAPP, Facebook and Opera news are rendering front line media services. Based on this, therefore, the paper reveals that new media have been potent at the awareness level. The paper also notes some differentials (gap) among the students in terms of level of awareness of COVID-19 pandemic terminology. This aspect of the result is hypothetically explained in the level of new media dependency, literacy level and income. The paper reinforces the role of the media in national development. The paper consequently recommends that governments and change agents take advantage of the possibilities inherent in the new media in the fight against COVID-19 pandemic.
\end{abstract}

Key Words: Mainstream media, Social media, Knowledge gap, Coronavirus, SARS-CoV-2, COVID-19

\section{INTRODUCTION}

Given the tremendous rise in user count of social media-especially Facebook and WhatsApp-in Nigeria, there has been a substantial change in the management of health, political, religious and social information in the country. To some extent, the communication equation in terms of freedom of information and power to reach the public has changed in favour of the public. More people are now able to share information freely and faster. This scenario was unthinkable before the year 2000. On this basis, communication and political discourses have changed in line with evolving media technological landscape.

The Internet is a precursor to this ongoing media change. In fact, the Internet has accelerated digital convergence with a range of players: Newspapers, magazines, radio, television, film, books. This convergence has led to the evolution of mixed media. Given the foregoing, it is important to understand the way the audience use Social Network Sites (SNS) in comparison with mainstream media.

\section{NEWS ALSO BREAKS FROM SOCIAL MEDIA!}

To many, news mainly breaks from social media. Many Nigerians first get fresh stories from social media. On May 12, 2017, soldiers mutinied in Ivory Coast demanding unpaid bonuses- singularity, conflict, violence and tragedy! May 22, 2017, a suicide bomber claimed the lives of 22 people including an eight-year-old girl in an explosion at the Ariana Grande pop concert in Manchester. The Islamic State terror group has claimed responsibility for the suicide bombing- conflict, violence and terror! In 2017, news broke that Chukwuma Onuekwusi, Channels Television's State House Correspondent, is dead. The veteran 
journalist died in the early hours of Tuesday, May 23- prominence and tragedy! (Uwakwe, 2017a).

Donald Trump, Republican, was inaugurated $45^{\text {th }}$ President of America January 20, 2017, succeeding Barack Obama, Democrat- change! After 100 days in office, President Trump has signed 34 executive orders, with far-reaching effects on Americans' lives and world politics. Friday, May 12, 2017, former President of Nigeria, General Ibrahim Badamasi Babangida, gave out his daughter, the last child and 2nd from his late wife Mariam Babangida, by name Halimat Babangida to the Sarkin Sudan Gombe, Alhaji Auwal Lawal Abdullahi in marriageprominence! Twenty six private jets as well as police and air force aircrafts landed in Minna on Friday, May 12, 2017 for the wedding. Aeroplanes brought the various dignitaries that attended the wedding of Babangida's daughter. The police also provided air surveillance and security while a cache of security agencies gave watch. Nigerians shared their private video clips on the spectacular event (Uwakwe, 2017a). All these were highly circulated in social media.

On Thursday, August 30, 2018, President of Senate, Abubakar Bukola Saraki, declared his presidential ambition under the platform of opposition Peoples Democratic Party, PDP. Senator Saraki made his ambition public at a dialogue with youth and young aspirants held at Sheraton Hotel under the auspices of the "Not Too Young to Run" movement and in the presence of the PDP National Chairman, Prince Uche Secondus in Abuja. This made instant news and was promptly shared by Nigerians in social media. During the Second Republic, the State media might choose to keep the news away from the public.

On July 13, 2015, information on the sacking of Service Chiefs in Nigeria was relayed through subscribing cell phones in Nigeria via the Guardian daily mobile news which costs thirty naira weekly. The information delivered through MTN platform: "President Buhari has sacked the Head of Army, Navy and Air force" (credited to http://wwngrguardiannews.com). This information was later retransmitted through social media. All the foregoing events were freely transmitted in social media and are an indication of the trend in information dissemination.

June 12, 2020, President Buhari addressed the nation and touched on COVID-19 pandemic. Shortly after the broadcast, many Nigerians began sharing the speech on social media. It enabled many Nigerians who usually do not have regular access to electricity to get informed online. In the United States, President Trump regularly tweets to Americans on COVID-19 and other world issues. Ahead of TV or radio broadcast, news on the disqualification of incumbent Governor Obaseki of Edo State also spread rapidly. The foregoing accounts are indicative of the power of social media.

\section{THE ISSUE}

March 11, 2020, the World Health Organisation (WHO) alerted the world on a novel coronavirus. The WHO continues to closely monitor the spread of the virus, said DirectorGeneral of the WHO, Tedros Adhanom, during the announcement. "We are deeply concerned both by the alarming levels of spread and severity, and by the alarming levels of inaction," he said. "We have called every day for countries to take urgent and aggressive action." By this time, there had been large outbreaks of the virus in Italy, South Korea, and the United States. The WHO classified the novel Coronavirus as a global public health emergency on January 30' 2020. On March 11, 2020, Tedros stated that "we have made an assessment that COVID 19 can be characterised as pandemic" (Wetsman, March 11, 2020). 
The mass media have always played important roles in promoting modernisation and development to people as well as articulating the views of the common man. Progressively, decades of technological milestones have dramatically changed the way news is produced and consumed (Uwakwe, 2017a). Media ecology is changing aggressively and the Internet is the prime agitator. But we were alerted by Dominick (2009) who saw them come together!

In Nigeria, with a cell phone of less than 10,000 naira or less, and active Internet network data bundle, you can sign in to the Facebook, WhatsApp, Twitter and similar social media. Even though these low-quality phones cannot be used anywhere in Europe and America, these affordable handsets have created opportunities for media access and rise in Internet use in Nigeria. In any case, irrespective of poor per capita income, media dependence in favour of the new media is on the rise. Several factors account for this phenomenon.

If your data bundle is adequate and the network is friendly, you can remain online as a king and navigate 24/7! As an online king, you can hunt and peddle information as you wish. And this ability may include bullying a political opponent or spread disinformation. This is media revolution. On the above basis, communication and political discourses have to change in line with media technological changes and new communication ecosystem. In part, this inevitable discussion on how people use social media prompted this work. In general, the work attempts to find out the roles of the social media in the management of COVID-19 information, and by so doing point out knowledge gap on COVID-19 pandemic based on social media.

Based on the foregoing, the following objectives and research questions are put forward.

\section{Objectives}

i. To determine the extent to which people rely on different media for information on COVID-19.

ii. To determine the extent to which people rely on social media as sources of information on COVID-19.

iii. To determine the extent to which people use information on social media.

iv. To determine the extent people are conversant with the pandemic terminology through social media.

\section{Research Questions}

1. To what extent do people rely on different media for information on COVID-19?

2. To what extent do people rely on social media as sources of information on COVID-19?

3. To what extent do people use information on social media?

4. To what extent are people conversant with the pandemic terminology through social media?

\section{LITERATURE REVIEW}

At a time in Nigeria, few privileged urban dwellers had access to broadcast services. At that time, the British Broadcasting Corporation (BBC) diffusion radio-wired radio system brought information to the city people. Information was mainly on colonial and government activities as well as world developments. Opinion leaders and the like information mongers were to retransmit such information to the less information privileged. In those days, it 
obvious that only a few had access to immediate political and social information. During this era, information circulation was slow, especially among rural people.

Today, a public event such as Democracy Day, or Governor Obiano's state broadcast could reach a very large population instantly. The power to reach large audiences is now enjoyed by many citizens. We now talk about citizen journalism and we live in an "electronic republic!"

In Nigeria, broadcasting began in Lagos first as wired system in 1933 as Radio Distribution System when the British Broadcasting Corporation (BBC) launched the first regulatory short wave programme service. This service was launched under the watch of the Department of Post and Telegraph (P\&T). Under this programme, radio signals were connected to speakers and making it possible for the public to hear the BBC foreign radio service in designated locations of subscribers. The service was a reception and relay base for the BBC. The service relayed the voices of the British administrators such as Winston Churchill and Bernard Shaw but also featured news and public affairs programmes. "The re-transmitted programmes encouraged the British administrators by informing them about events in Britain. It also gave the colonized people a view of the imperial authority of Britain" (Owuamalam, 2008, p.10).

On December 1, 1935, the Radio Distribution System was changed to Radio Diffusion System. The aim was to spread the activities of the British colonial government and her allies and was used to spread the World War 11 information and propaganda. With a new name, Radio Distribution System took off with stations at Ikeja and the other in the Glover Memorial Hall. Diffusion subscribers paid for the listening boxes. In time, stations were opened in Ibadan (1939), Kano (1944) and later in Enugu, Kaduna, Jos, Zaria, Calabar and Port Harcourt. Opinion leaders and the like information mongers were to retransmit such information to the less information privileged. In those days, it was obvious that only a few had access to immediate political and social information. Thus it is obvious that desire to reach the public as fast as possible has been in the front burners of colonial administration till date.

In April 1951, The RDS changed to Nigeria Broadcasting Service and radio stations were established in Lagos, Kaduna, Enugu and Ibadan. The stations were broadcasting on both short and medium waves, which till today is a government monopolised waves. The NBS Act was enacted in 1956. However, by another Act of Parliament, this service was later reorganised into Nigerian Broadcasting Corporation on April 1, 1957.

We see that from the beginning, broadcasting arrived under the control of the government, serving mainly as a medium of propaganda and for controlling the information. All these have changed.

\section{NEW TECHNOLOGIES HERALD CHANGES}

Media ecology is changing forcefully across the globe, and the Internet is the prime change agent (Uwakwe, 2018). Generally, technology has caused massive changes and traditional or mainstream journalists know this revolution. Today, professionals explain the new media landscape in various terms! You may have heard of the e-editorial board! You may have heard of global Public Square meaning world capacity to share ideas communally and faster. You may also hear of virtual citizenship -capacity of digitally compliant fellows to enjoy worldwide interaction and neighbourhood. Any mass communication specialist operating 
without basic knowledge of the electronic world and new media is doing so at a great disadvantage. Media practitioners now talk about "digital natives" and "digital immigrants", etc.

The Internet has been busy redefining the old process and irreversibly doing a revolution. In fact, it has put a question mark on what used to be the traditional features of the mass media and examples abound. Think of the changes: First, an individual can communicate with a large audience - one to many model process - which traditionally is the function of an organization or a corporation. Second, the traditionally delayed feedback has become immediate on the Internet. Third, this Internet induced redefinition of the elements of the mass communication process is refocusing attention on issues such as freedom of "expression, privacy, responsibility, and democracy" (Baran, 2002, p. 83).

You may have heard of "open source journalism," or "citizen journalism," which describes a process by which citizens, the ordinary, acting as amateur journalists without pay, submit information to Web sites such as YouTube and Facebook. You too can upload your information, and within minutes, could be shared worldwide

\section{COVID-19}

The COVID-19 pandemic is putting words in the mouths of billions of people worldwide. Ventilator, BiPap, face coverings, homemade masks, PPE are words quickly becoming part of our daily terminology as the disease COVID-19, which has now killed more than 74,000 people around the globe, continues to spread (Dolcourt, April 8, 2020).

Currently, there are over 7 million confirmed cases worldwide. As of June 12, 2020, Nigeria has about 15,181 confirmed cases, 399 deaths but also recorded 4,891 discharged patients. Arising from this, educating yourself on the science and the social responses will help you understand the situation and help explain it to others (Dolcourt, April 8, 2020) and perhaps help in better management of the pandemic.

\section{THEORETICAL REVIEW}

Due to rapid changes in the media landscape, more extensive theoretical studies are needed to understand the dynamics of digital communication (Ezepue, 2019, pp.1-15). In any case, two theories-Media Ecology and Knowledge Gap help shape the work.

\section{Knowledge Gap Theory}

Back in the summer of 1970, three researchers published an article called "Mass Media Flow and Differential Growth in Knowledge". These researchers, P. J. Tichenor, G. A. Donohue, and C. N. Olien, proposed something known as the knowledge gap hypothesis (Artem, 2018). The knowledge Gap theory is the notion that individuals with a higher socio-economic status absorb information presented by mass media at a faster rate than those with a lower socioeconomic status. This leads to an increased gap in knowledge between these two segments of society as a result (Artem, 2018). It posits that as more and more information is made available to a people, more socially privileged groups will acquire more information at a faster rate than less privileged groups so that the relative gap between them will increase (Cecilie, 2019). In simple words, as the access to mass media increases those particular segments of population inevitably gain information faster and hence the wide gap increases with the lower economic status of the population (n.a.). 
Volume 1 Number 2

Media Ecology Theory: Media ecology argues that media act as extensions of the human senses in each era, and communication technology is the primary cause of social change (Hakanen, 2007). The theory, therefore, is concerned with the study of media, technology, and communication and how they affect human environments (West \& Turner 2014). The theoretical concepts were proposed by Marshall McLuhan in 1964 (McLuhan, 1964).

\section{METHODOLOGY}

The research approach is the quantitative research design and adopts the survey method. This is because the survey method can measure belief, idea, opinion, attitude, and behaviour. This method has also the ability to allow for descriptive and inferential analysis and interpretation.

\section{Population of Study}

The population comprises current students of Mass Communication, Federal Polytechnic, Oko Anambra State, Nigeria officially put by registry unit at 320.

\section{Sample and Sampling Procedure}

A sample of 120 respondents was purposely drawn for the study. The decision was guided by the need to include students who have access to the Internet as they have the characteristics for the study. At the point of retrieving the questionnaire, 8 students were unreachable. Therefore, a sample of 112 was used for the study.

\section{Instrument of Data Collection}

The researcher made use of a questionnaire.

\section{Method of Data Collection}

The researcher personally retrieved the by online returns. Where online returns were difficult, the researcher used the telephone interview with the questionnaire as a guide.

\section{Method of Data Presentation and Analysis}

The data collected by the researcher was presented in tables and analysed in percentages.

\section{DATA ANALYSIS}

Table 1: Access to Online Media

\begin{tabular}{|l|l|l|}
\hline & Response & Percentage \\
\hline Yes & 112 & 93.3 \\
\hline No & 8 & 6.6 \\
\hline Total & 120 & 100 \\
\hline
\end{tabular}

Based on the above and in line with the objectives of the study, 112 respondents were adopted as a more useful sample. The table is also indicative of the rise of Internet access in Nigeria and a signpost to the online penetration among students. Over 100 million Nigerians are now connected to the internet, with 250,000 new subscribers logging on in the last quarter of 2019, according to data from the Nigerian Communications Commission (Russon, February 20, 2020).

Table 2: Major Source of information

\begin{tabular}{|l|l|l|}
\hline ITEM & Response & Percentage \\
\hline TV & 10 & 8.9 \\
\hline & & \\
& &
\end{tabular}


NNAMDI AZIKIWE UNIVERSITY Journal of COMMUNICATION A

Volume 1 Number 2

\begin{tabular}{|l|l|l|}
\hline Radio & 12 & 10.7 \\
\hline Newspaper & 8 & 7.14 \\
\hline Magazines & Nil & Nil \\
\hline Interpersonal & 11 & 9.8 \\
\hline $\begin{array}{l}\text { Internet-related } \\
\text { sources }\end{array}$ & 71 & 63.3 \\
\hline Total & 112 & 100 \\
\hline
\end{tabular}

Table 3: Comparative sources of online information

\begin{tabular}{|l|l|l|}
\hline ITEM & Frequency & Percentage \\
\hline WhatsApp & 43 & 38.39 \\
\hline Facebook & 25 & 22.32 \\
\hline Twitter & 2 & 1.78 \\
\hline Yahoo/Google News & 3 & 2.67 \\
\hline Opera News & 22 & 19.64 \\
\hline Personal Blogs & 7 & 6.25 \\
\hline $\begin{array}{l}\text { Internet-based } \\
\text { mainstream media } \\
\text { (TV/Radio/newspaper on } \\
\text { net }\end{array}$ & 10 & 8.92 \\
\hline Total & 112 & 100 \\
\hline
\end{tabular}

Tables 2 and 3 above shed light on the objective of the study. A recent survey of 819 individuals and 48 retailers and phone sellers from seven Nigerian states that overall, respondents were interested in owning a phone and having mobile internet (Wang, March 4, 2020). WhatsApp accounts for the greatest source of information from social media. This is an indication that the site is popular among students and, perhaps, many Nigerians.

This is followed by Facebook and Opera news. The paper highlights the current strength of Opera as a source of news. This is consistent with earlier industry study which shows that respondents have a specific perception of Internet content that is very different from that of the developed world. For example, using Opera, a major web browser app, is seen as synonymous with "browsing the internet." This leads to the unintended consequence of users not discovering the browser app that comes with their mobile device if the app icon does not look similar to the Opera icon (Wang, March 4, 2020). In any case, some studies suggest that when Nigerians go online (predominantly with their mobile phones) they spend much of their time on social media platforms (Facebook, Twitter, YouTube and so on).

Table 4: How people use online information on the pandemic

\begin{tabular}{|l|l|l|}
\hline & Response & Percentage \\
\hline share to individuals & 51 & 45.53 \\
\hline Share to groups & 33 & 29.46 \\
\hline Keep privately & 5 & 4.46 \\
\hline Discuss with people & 17 & 15.17 \\
\hline Take no action & 6 & 5.35 \\
\hline & 112 & 100 \\
\hline
\end{tabular}

From the table, users retransmit information to friends and relatives and they also discus developments verbally. This accounts for why information on the Internet spreads rapidly. 
Agbanu (2013, p. 95) states that "people are no longer passive receivers of information, but active partners in most communication processes." The New York Times Customer Insight Group partnered with Latitude Research to conduct a three-phase study to understand why people share online - which included interviews, a sharing panel, and a survey of 2,500 medium-to-heavy online sharers (Eleventy Marketing Group, October. 6, 2015). The study has some findings based on "The Psychology of Sharing" study that gives a glimpse at what could inspire or motivate someone to share a link, deal, video or picture online.

The study further breaks it down into different motivations. It comes down to four primary drivers:

For YOU

To help, entertain or enlighten someone else.

For I

To say something about who you are and what you stand for.

For WE

To build or maintain a relationship with a person or group.

For THEM

To help, support or draw attention to something you care about (Eleventy Marketing Group, 2015).

Table 5: Awareness of Basic COVID-19 Terminology

\begin{tabular}{|l|l|l|}
\hline ITEM & Yes & No \\
\hline Index case & $43(38.39 \%)$ & $69(61.60 \%)$ \\
\hline Pandemic & $90(80.35 \%)$ & $22(19.64 \%)$ \\
\hline SARS-CoV-2 & $46(41.07 \%)$ & $66(58.92 \%)$ \\
\hline COVID-19 & $92(82.14 \%)$ & $20(17.85 \%)$ \\
\hline Coronavirus & $112(100 \%)$ & Nil $(0 \%)$ \\
\hline Mitten the curve & $10(8.92 \%)$ & $102(91.07 \%)$ \\
\hline Social distancing & $88(78.57 \%)$ & $24(21.42 \%)$ \\
\hline $\begin{array}{l}\text { Self isolation/ } \\
\text { quarantine }\end{array}$ & $70(62.5 \%)$ & $42(37.5 \%)$ \\
\hline Isolation Centre & $87(77.67 \%)$ & $25(22.32 \%)$ \\
\hline
\end{tabular}


NNAMDI AZIKIWE UNIVERSITY Journal of COMUUNICATTON AND MEDLA STUDIES

Volume 1 Number 2

\begin{tabular}{|l|l|l|}
\hline Community spread & $66(58.92 \%)$ & $46(41.07 \%)$ \\
\hline Positive cases & $112(100 \%)$ & Nil $(0 \%)$ \\
\hline Active cases & $110(98.21 \%)$ & $2(1.78 \%)$ \\
\hline Testing & $112(100 \%)$ & Nil $(0 \%)$ \\
\hline Nose Mask & $112(100 \%)$ & Nil $(0 \%)$ \\
\hline Sanitiser & $112(100 \%)$ & Nil $(0 \%)$ \\
\hline Hand wash & $112(100 \%)$ & Nil $(0 \%)$ \\
\hline
\end{tabular}

The above table describes the level of awareness of issues relating to the pandemic. Of importance is the fact that all respondents are aware of the pandemic. They are also aware of some key issues about the pandemic such as hand wash, sanitizer and nose mask. There are some differentials (gap) among the students in terms of level of awareness of COVID-19 pandemic. This is hypothetically explained in the level of new media dependency, literacy level and income.

This aspect of the work also relates to Dependency theory of the media. Sandra BallRokeach and Melvin DeFleur proposed the "Dependency theory" in 1976 and scholars agree the theory was expanded from the Uses and Gratifications theory. The Dependency theory (also called media system dependency theory or simply dependency theory) holds that the mass media's influence varies based on how much people need or use particular media (Bentley, n.d.).

\section{CONCLUSION}

It is important to note that public responsiveness to government and non-government initiatives remains critical to world development drive. Consequently, using social media to propagate development initiatives such as improved health has been the practice the world over. This practice remains crucial in the fight against COVID-19. The theories used in the paper were appropriate and have buttressed the work. We can conclude:

- $\quad$ More and more people are getting access to online services

- $\quad$ Not every person has access to online media.

- Opera browser is a significant source of online information.

- WhatsApp and Facebook remain attractive to many online users.

- $\quad$ Many people are aware of coronavirus and fewer number are aware of COVID-19.

- $\quad$ Coronavirus, Facemask, sanitizer appear to be a house-hold name.

- There are some differentials (gap) among the students in terms level of awareness of COVID-19 pandemic. This is hypothetically explained in the level of new media dependency, literacy level and income.

\section{RECOMMENDATIONS}

The following recommendations are made: 
Volume 1 Number 2

1. Workshops and seminars for professional journalists are necessary for sensitisation on online journalism and user-generated contents. This is expected to help guard against fake news associated with online media.

2. The curriculum in mass communication related departments should be enriched to accommodate critical areas of new media and online journalism. This will include teachings in media literacy.

3. Secondary school curriculum should incorporate salient areas of new media to deal with issues in user-generated contents.

4. Religion has been described as the opium of the masses. Consequently, religious practitioners should be considered partners in any attempt to fight a war against COVID-19.

5. National crusade focusing on restraints in sharing unverified information and fake news is important. This will help reduce the incidents and consequences of fake news and fake medical advisory on COVID-19. In some instances, people were asked to take salt, drink chloroquine without dosage, take excessive Vitamin C, etc.

6. In line with the study, it has become pertinent that governments and change agents take advantage of the possibilities inherent in the new media in the fight against COVID-19 pandemic.

7. Development of acceptable online news ethical values at national and international levels cannot be over-emphasised in any new media literature.

\section{REFERENCES}

Agbanu, V. (2013). Mass communication: Introduction, techniques, issues. Enugu: Rhyce kerex Publishers

Artem, C. (January 3, 2018). Knowledge Gap Hypothesis: Definition \& Analysis, retrieved from https://study.com/academy/lesson/knowledge-gap-hypothesis-definitionanalysis.html.

Dolcourt, J. (April 8, 2020). Coronavirus glossary: Every COVID-19 related term you need to know https://www.cnet.com/how-to/coronavirus-glossary-every-covid-19-relatedterm-you-need-to-know, retrieved May 5, 2020

Baran, S. (2002). Introduction to mass communication. New York: Mc Graw-Hill.

Bentley, J.M. (n.d.) Media dependency theory. In C.E. Carroll The SAGE Encyclopedia of Corporate Reputation DOI: http://dx.doi.org/10.4135/9781483376493.n170, retrieved May 11, 2020.

Cecilie, G. (29 April 2019). Knowledge gap hypothesis and journalism. https://doi.org/10.1002/9781118841570.iejs0025, retrieved May 12, 20120

Dominick, J. (2009). The dynamics of mass communication. $\left(10^{\text {th }}\right.$ ed.). New York: Mc-GrawHill.

Eleventy Marketing Group (October 6, 2015). 9 Insights into what compels people to share online, https://eleventygroup.com/2015/10/06/what-compels-people-to-share-online/ retrieved. May 11, 2020.

Ezepue, E (2019). Patterns of new media: A theoretical review. In K.A.Omenugha, Adeba 
F and Ngugui, C.M (eds.). New media and African Society. Nairobi: Nairobi Academic Press, pp.1-15.

Hakanen, E. (2007). Branding the teleself: Media effects discourse and the changing self. Lanham, MD: Rowman \& Littlefield.

McLuhan, M. (1964). Understanding media. New York: Mentor.

Nuwer, R. (November 22, 2018). The Flu that swept the world. https://www.bbc.com/future/article/20181120-what-if-a-deadly-influenza-pandemicbroke-out-today, retrieved May 12, 2020

Owuamalam, E.O (2008). Elements of broadcasting. Owerri: Top Class Publishers

Russon, M. (February 20, 2020). How internet access is improving in Nigeria https://www.bbc.com/news/business-51377955, retrieved June 10, 2020

Uwakwe, O. (2017a). Media writing and reporting (4 ${ }^{\text {th }}$ ed.). Enugu: Cecta

Uwakwe, O. (2017b). New media and online journalism. Enugu: Cecta.

Uwakwe, O. (2018). Spreading maternal health through the mass media and word of mouth in south east Nigeria: Lessons from 2015 millennium goals. Global Communicator, Vol 3, number 1, pp.11-27.

Uwakwe, O. (2019). New media and online journalism. Enugu: Cecta.

Wang, Y. ( March 4, 2020). First-time internet users in Nigeria use the internet in a unique way. https://www.kaiostech.com/first-time-internet-users-in-nigeria-use-the-internetin-a-unique-way-heres-why-that-matters/retrieved May 11, 2020.

Wetsman , N. (March 11, 2020) WHO declares the outbreak of the new coronavirus is a pandemic https://www.theverge.com/2020/3/11/21156325/coronavirus-pandemicwho-declares-covid-19-outbreak-global-h1n1, retrieved June 12, 2020 